Online: http://e-journal.sari-mutiara.ac.id/index.php/KesehatanMasyarakat

DOI: https://doi.org/10.51544/jkmlh.v6i1.1675

\title{
GAMBARAN PENGETAHUAN DAN SIKAP SISWA SMAN BALUNG TERHADAP BAHAYA STYROFOAM SEBAGAI WADAH MAKANAN
}

\author{
Teny Kurniasari ${ }^{1}$ a) ${ }^{\text {Sudarti }}{ }^{2}$, b) ${ }^{2}$ achju Subhan $^{3}$ \\ ${ }^{1}$ Mahasiswa S2 Pascasarjana Pendidikan IPA Universitas Jember \\ ${ }^{2,3}$ Dosen Pendidikan Lingkungan Hidup Pascasarjana Pendidikan IPA Universitas Jember \\ Jalan Kalimantan No. 37 Sumbersari Jember \\ a)tenykurniasari.tk26@gmail.com \\ b)sudarti.fkip@unej.ac.id
}

Received: Januari 2021; Accepted: April 2021; Published: Juni 2021

\begin{abstract}
ABSTRAK.
Penggunaan Styrofoam sebagai wadah makanan saat ini sangat banyak digunakan. Hal ini dilakukan oleh masyarakat tanpa mengetahui bahaya dari penggunaan tersebut. Di Indonesia belum ada peraturan yang melarang penggunaan Styrofoam ini, padahal bahaya yang ditimbulkan sangat besar. Penelitian sederhana ini dilakukan untuk mengetahui pengetahuan dan respon siswa SMAN Balung terhadap bahaya penggunaan Styrofoam sebagai wadah makanan sehingga bisa digunakan sebagai bahan pertimbangan dalam mencari alternatif bahan lain untuk mengatasi dampak yang ditimbulkan akibat penggunaan Styrofoam. Penelitian yang dilakukan termasuk jenis penelitian deskriptif. Populasi sampel adalah siswa SMAN Balung kelas XII MIPA tahun ajaran 2020-2021. Data tentang pengetahuan dan sikap didapat melalui pedoman kuisioner. Dari hasil penelitian diperoleh bahwa gambaran pengetahuan siswa SMAN Balung kelas XII MIPA tahun ajaran 2020/2021 akan bahaya penggunaan Styrofoam sebagai wadah makanan adalah termasuk dalam kategori sedang sebanyak 64 orang (53,78\%), kategori baik sebanyak 40 orang $(33,61 \%)$ dan kategori kurang sebanyak 15 orang (12,6\%). Sedangkan untuk gambaran sikap siswa SMAN Balung kelas XII MIPA tahun ajaran 2020/2021 tentang bahaya penggunaan Styrofoam sebagai wadah makanan dalam kategori positif sebanyak 86 orang $(72,26 \%)$ dan dalam kategori negatif sekitar 33 orang (27,73\%).Disarankan bagi siswa SMAN Balung kelas XII MIPA tahun ajaran 2020/2021 untuk terus meningkatkan pengetahuan tentang bahaya penggunaan Styrofoam sebagai wadah makanan sehingga diperoleh data yang lebih akurat yang dapat dijadikan dasar dalam mengambil langkah preventif untuk menghindari berbagai masalah yang ditimbulkan. Sikap yang positif dalam menghindari penggunaan Styrofoam sebagai wadah makanan harus terus ditingkatkan untuk menghindari bahaya penggunaan Styrofoam sebagai wadah makanan.
\end{abstract}

Kata Kunci : Wadah Makanan, Perilaku Siswa, Styrofoam

wadah alat elektronik saja, tapi Styrofoam

\section{PENDAHULUAN}

sekarang banyak digunakan sebagai wadah

Dalam kehidupan sehari-hari kita sudah tidak asing lagi dengan wadah yang terbuat dari bahan Styrofoam. Tidak hanya untuk berbagai macam makanan. Sebut saja seblak, ayam geprek, nasi goreng, bahkan resto yang menyajikan makanan siap sajipun sekarang banyak yang menggunakan 
Online: http://e-journal.sari-mutiara.ac.id/index.php/KesehatanMasyarakat

DOI: https://doi.org/10.51544/jkmlh.v6i1.1675

Styrofoam. Bahan ini banyak digunakan karena harganya yang murah dan dari segi kepraktisannya sehingga mudah dibawa kemana-mana.

Sebenarnya, orang sudah banyak yang mengetahui tentang bahaya dari pengunaan Styrofoam terhadap kesehatan dan juga lingkungan. Akan tetapi, masyarakat sepertinya sudah ketagihan dan tidak ada pilihan bahan lain yang memiliki harga murah dan mudah ditemukan.

Di Indonesia sendiri masih belum ada peraturan yang melarang penggunaan Styrofoam sebagai wadah makanan. Sebenarnya di kota Bandung sebenarnya sempat diberlakukan larangan penggunaan Styrofoam, namun sepertinya larangan itu tidak diikuti oleh kota-kota yang lain di Indonesia. Menurut Rappler, 2016, Wali kota Bandung menjelaskan larangan penggunaan Styrofoam didasarkan alas an kesehatan dan lingkungan.

Penelitian sederhana ini dilakukan untuk mengetahui pengetahuan dan respon siswa SMAN Balung terhadap bahaya penggunaan Styrofoam sebagai wadah makanan sehingga bisa digunakan sebagai bahan pertimbangan dalam mencari alternatif bahan lainnya untuk mengatasi dampak yang ditimbulkan akibat penggunaan Styrofoam itu sendiri.

\section{METODE PENELITIAN}

Penelitian yang dilakukan ini termasuk jenis penelitian deskriptif yang digunakan untuk mengetahui pengetahuan dan sikap siswa yang merupakan konsumen, terhadap bahaya dari penggunaan Styrofoam sebagai wadah makanan. Penelitian ini berlokasi di SMA Negeri Balung yang dialkasanakan pada bulan November sampai Desember 2020. Populasi sampelnya adalah siswa siswi SMA Negeri Balung kelas XII MIPA tahun ajaran 2020/2021.

Sampel merupakan keseluruhan populasi berdasarkan kriteria inklusi dan eklusi. Sampel inklusi disini yaitu seluruh siswa SMA Negeri Balung tahun ajaran 2020/2021 yang merupakan seluruh sampel dengan jumlah 240 siswa. Sedangkan yang termasuk sampel eklusi yaitu siswa SMA Negeri Balung Kelas XII MIPA tahun ajaran 2020/2021 yang tidak mengisi lembar googleform. Yang termasuk data primer dalam penelitian ini yaitu data yang diperoleh dari hasil pengisian googleform yang berupa data usia, dan jenis kelamin siswa. Untuk data tentang pengetahuan dan sikap didapat melalui pedoman kuisioner. Sedangkan data sekunder diperoleh dari lokasi penelitian yang berupa gambaran atau fenomena umum yang terjadi di SMA Negeri Balung khususnya kondisi pada saat sebelum pandemik seperti saat ini.

\section{HASIL DAN PEMBAHASAN}

Data yang diperoleh berdasarkan hasil penelitian yang telah dilakukan adalah sebagai berikut :

Informasi mengenai responden yang terdiri atas usia dan jenis kelamin, diperoleh bahwa responden dengan usia antara 18 tahun yaitu sebanyak 49 orang atau sekitar $41,17 \%$, merupakan responden terbanyak, dapat dilihat di Tabel. 1.

TABEL 1. UMUR RESPONDEN

\begin{tabular}{cc}
\hline Umur & Jumlah \\
\hline 16 & 39 \\
17 & 17
\end{tabular}


Online: http://e-journal.sari-mutiara.ac.id/index.php/KesehatanMasyarakat

DOI: https://doi.org/10.51544/jkmlh.v6i1.1675

Sedangkan menurut Tabel 2., untuk kriteria jenis kelamin, responden terbanyak yaitu perempuan dengan jumlah 86 orang $(72,3 \%)$. Berdasarkan hasil survey yang telah dilakukan, untuk kategori pengetahuan dapat dimasukkan ke dalam kategori baik, sedang dan kurang.

TABEL 2 . JENIS KELAMIN RESPONDEN

\begin{tabular}{cc}
\hline Jenis Kelamin & Jumlah \\
\hline Laki-laki & 33 \\
Perempuan & 86 \\
\hline
\end{tabular}

Untuk responden yang termasuk kategori sedang berdasarkan Tabel 3 adalah sebanyak 64 orang atau sekitar 53,78\%. Hasil pengetahuan responden dilihat dari pengetahuan awal responden tentang jenis dari Styrofoam itu sendiri, kode yang tertera pada Styrofoam yang termasuk ke dalam salah satu jenis plastik, dan bahaya penggunaan Styrofoam sebagai tempat makanan.

TABEL 3. KATEGORI RESPONDEN DALAM ASPEK PENGETAHUAN

\begin{tabular}{cccc}
\hline No & Kategori & Jumlah & Persentase \\
. & & & \\
\hline 1 & Baik & 40 & 33,61 \\
2 & Sedang & 64 & 53,78 \\
3 & Kurang & 15 & 12,6 \\
\hline
\end{tabular}

Berdasarkan Tabel 4., untuk kategori sikap responden termasuk pada kategori positif dengan jumlah responden sebanyak 86 responden atau 72,26\%. Untuk kategori sikap ini dilihat dari cara siswa dalam menghadapi berbagai fenomena penggunaan Styrofoam sebagai wadah makanan dalam kehidupan sehari-hari, cara penanganan sampah Styrofoam dan cara siswa menemukan alternative solusi untuk mengganti wadah Styrofoam sebagai tempat makanan.

TABEL 4 .KATEGORI RESPONDEN DALAM ASPEK SIKAP

\begin{tabular}{cccc}
\hline No & Sikap & Jumlah & Persentase \\
. & & & 72,76 \\
\hline 1 & Positif & 86 & 27,73 \\
\hline
\end{tabular}

\section{PEMBAHASAN}

Responden dalam penelitian ini adalah responden yang berusia antara 16 sampai 19 tahun. Dengan responden yang berusia 18 tahun yang terbanyak dengan jumlah 49 orang atau sekitar 41,17\%.

Berdasarkan hasil pengetahuan responden, diketahui bahwa secara umum responden telah mengetahui tentang 
Online: http://e-journal.sari-mutiara.ac.id/index.php/KesehatanMasyarakat

DOI: https://doi.org/10.51544/jkmlh.v6i1.1675

kelebihan dan kekurangan dari bahan Styrofoam sebagai wadah makanan. Kelebihan dari bahan ini yaitu memiliki harga murah, mudah didapat serta dapat dibawa kemana-mana. Menurut $F$. Widyaningsih, 2010, plastik kresek dan styrofoam menjadi andalan pedagang makanan siap saji karena relatif murah, mudah didapat, tidak korosif, beban ringan dan kuat. Kelebihan inilah yang menyebabkan sebagian besar para pedagang banyak yang memanfaatkan Styrofoam sebagai wadah makanan maupun minuman. Styrofoam merupakan salah satu jenis plastic dengan kode 6 yang monomernya berupa stirena, benzene dan formalin. Senyawa-senyawa ini telah banyak diketahui dapat memberikan dampak negatif terhadap kesehatan manusia. Pengetahuan responden tentang hal ini masih tergolong rendah, dimana terdapat 87 orang atau $73,1 \%$ responden yang masih belum mengetahui tentang bahaya Styrofoam jika digunakan sebagai wadah makanan dalam kehidupan sehari-hari.

Berdasarkan teori, stirena dapat mengurangi produksi sel darah merah yang sangat dibutuhkan tubuh untuk mengangkut sari pati makanan dan oksigen ke seluruh tubuh. Akibatnya, fungsi saraf seseorang bisa terganggu, sehingga ia akan mengalami kelelahan, gelisah, dan susah tidur. Stirena juga bisa memengaruhi kondisi janin melalui plasenta ibu dan berpotensi mencemari ASI. Kandungan benzena juga sangat berbahaya. Benzena yang masuk ke dalam tubuh akan tersimpan dalam jaringan darah. Kandungan ini tidak dapat larut dalam air, sehingga tidak bisa dikeluarkan melalui urin maupun feses, dan akan menumpuk pada lemak di dalam tubuh. Hal inilah yang menyebabkan timbulnya penyakit kanker. Kandungan benzene akan berpindah dengan cepat begitu terkena uap panas dari makanan yang dimasukkan ke dalam Styrofoam. Berdasarkan berbagai penelitian yang dilakukan sejak tahun 1930an, diketahui bahwa styrene, bahan dasar Styrofoam, juga butadiene sebagai bahan penguat, maupun DOP atau BHT sebagai plasticizer-nya bersifat mutagenik (mampu mengubah gen) dan potensial karsinogen (merangsang pembentukan sel kanker) (Yuliarti, 2007).

Sebagian besar responden juga tidak mengetahui bagaimana cara menangani sampah Styrofoam dengan benar. Menurut teori, EPA limbah styrofoam sulit terurai secara alami dan jika dalam penangannya tidak baik, maka akan menghasilkan 57 zat berbahaya ke udara (Ali Mahmudi, 2017). Styrofoam jika dibakar akan menghasilkan zat dioksin yang berbau menyengat. Hal ini disebabkan pengetahuan siswa tentang bahaya Styrofoam masih sangat minim. Dioksin adalah suatu zat beracun dan merupakan penyebab kanker serta dapat mengurangi sistem kekebalan tubuh seseorang (Sumbung, 2012).

Berdasarkan hasil survey diketahui bahwa pengetahuan tentang bahaya penggunaan Styrofoam sebagai wadah makanan termasuk ke dalam kategori sedang. Menurut pendapat peneliti hal ini disebabkan karena minimnya sumber informasi yang diperoleh oleh siswa. Siswa memperoleh informasi hanya berdasarkan dari sesuatu yang mereka lihat dalam kehidupan sehari-hari tanpa melakukan studi literatur yang relevan terhadap informasi yang mereka peroleh. Hal ini sesuai dengan teori yang menyebutkan bahwa sebagian besar pengetahuan manusia diperoleh melalui mata dan telinga. Pengetahuan juga dapat diperoleh dari pengalaman sendiri maupun orang lain (S. Notoatmodjo, 2011). 
Online: http://e-journal.sari-mutiara.ac.id/index.php/KesehatanMasyarakat

DOI: https://doi.org/10.51544/jkmlh.v6i1.1675

Dengan demikian dapat disimpulkan bahwa pengetahuan yang dimiliki oleh siswa termasuk ke dalam kategori sedang, karena informasi yang mereka peroleh tentang penggunaan Styrofoam sebagai wadah makanan masih belum benar.

Adanya keinginan dari beberapa siswa untuk mengganti wadah makanan dengan bahan lain seperti daun pisang atau plastik adalah sebanyak $85,7 \%$. Dengan jumlah sebanyak ini seharusnya siswa lebih bijak dalam membeli makanan yang ada di sekitarnya dengan mengamati kemasan yang digunakan sebagai wadah makanan atau minuman. Kemasan styrofoam tidak digunakan sebagai tempat makanan dan minuman panas sebanyak 42 responden atau sebanyak $35,2 \%$. Menurut asumsi peneliti bahwa pengetahuan siswa yang tergolong sedang akan membawa pada perubahan sikap yang positif. Penelitian Ilmiawati (2017) tentang edukasi pemakaian plastik sebagai kemasan makanan dan minuman serta resiko terhadap kesehatan menyebabkan perubahan sikap terhadap penggunaan plastik yang baik dan benar. Hal ini menunjukkan bahwa secara umum siswa dapat mengubah perilakunya dengan tidak menggunakan Styrofoam sebagai wadah makanan dan minuman yang panas.

Sikap responden terhadap penolakan jika diberi makanan atau minuman yang menggunakan Styrofoam sebagai kemasannya ada sebanyak $57,1 \%$ atau sebanyak 68 orang yang menolak. Banyaknya responden yang menolak tersebut sebenarnya juga menunjukkan sikap yang benar. Namun disisi lain ada sebanyak $42,9 \%$ atau 51 orang responden menjawab menerima jika diberi makanan yang menggunakan bahan Styrofoam sebagai wadah makanan.
Selanjutnya ada beberapa responden yang merasa bahwa pencantuman kode yang terdapat pada Styrofoam itu tidak begitu penting, sehingga mereka bersikap tidak menyetujui hal ini. Hal ini disebabkan pengetahuan mereka tentang kode yang terdapat pada bahan plastic masih sangat minim. Sikap berikutnya yaitu tentang pernyataan tentang cara penanganan makanan yang akan dimasukkan ke dalam wadah Styrofoam, bahwa makanan perlu didinginkan terlebih dahulu sebelum dimasukkan ke dalam wadah Styrofoam. Dari sini diperoleh bahwa banyak responden yang berpendapat kurang setuju dan bahkan tidak setuju, yaitu sebanyak 85 orang atau $71 \%$. Hal ini juga sama dengan pengetahuan mereka yang menunjukkan bahwa boleh menggunakan Styrofoam untuk makanan panas. Sementara berdasarkan teori yang ada, plastik bersifat termoplastik, artinya dapat meleleh pada suhu tertentu dan melekat mengikuti perubahan suhu (Setyowati, 2017). Jadi pengetahuan siswa SMAN Balung akan sifat Styrofoam sebagai salah satu jenis plastic diantaranya mudah meleleh pada suhu tinggi masih sangat kurang.

Sikap responden yang menunjukkan hanya menggunakan Styrofoam sebagagai wadah makanan yang tidak lebih dari tiga kali dalam seminggu yaitu sebanyak 99 orang atau $84,2 \%$. Hal ini menunjukkan sikap positif yang diberikan oleh siswa kelas XII MIPA SMA Negeri Balung tahun ajaran 2020/2021 mengingat akan bahaya penggunaan Styrofoam sebagai wadah makanan. Sudah dijelaskan sebelumnya senyawa yang ada dalam Styrofoam dapat memicu adanya kanker. Menurut peneliti, sikap siswa dalam mencegah bahaya Styrofoam terhadap kesehatan juga merupakan sikap yang positif. Sebagian 
Online: http://e-journal.sari-mutiara.ac.id/index.php/KesehatanMasyarakat

DOI: https://doi.org/10.51544/jkmlh.v6i1.1675

responden juga memilih penggunaan bahan lain yang lebih alami dan tidak mengganggunkesehatan ketika digunakan sebagai wadah makanan, seperti misalnya penggunaan daun pisang. Berdasarkan hasil survey ada sebanyak 102 responden $85,8 \%$, yang memilih solusi menggunakan daun pisang sebagai wadah makanan karena mereka anggap lebih aman daripada penggunaan Styrofoam sebagai wadah makanan. Pengetahuan yang baik atau sedang terhadap sesuatu akan menghasilkan sikap yang positif yang ditunjukkan sebagai respon atas suatu fenomena. Sikap belum merupakan suatu tindakan atau aktifitas, akan tetapi merupakan "predisposisi" tindakan atau perilaku (Notoatmodjo, 2011).

Sikap yang baik terkait dengan masalah kesehatan pada dasarnya merupakan sikap dan kebiasaan seseorang dalam menjalankan hidup sehari-hari. Perubahan sikap dalam kebiasaan hidup sehat disebabkan karena adanya rangsangan yang mengikat diri seseorang. Berdasarkan teori disebutkan bahwa perubahan perilaku kesehatan terjadi karena adanya proses korelasi antara stimulus (sebagai independent variable) terhadap respon yang terjadi (sebagai dependent variable) (Ryadi, 2016). Setiap perilaku dan sikap seseorang ini merupakan suatu bentuk pencegahan terhadap penyakit. Oleh karena itu perubahan sikap yang didahului dengan pengetahuan yang baik tentang masalah kesehatan sangat diperlukan. Sikap responden dalam penelitian ini menunjukkan sikap yang positif terhadap penggunaan Styrofoam sebagai wadah makanan. Kebiasaan dan sikap hidup sehat tidak hanya ditentukan oleh pengetahuan terhadap hidup sehat itu sendiri melainkan juga dipengaruhi oleh aspek kejiwaan atau emosional, kebiasaan, kondisi lingkungan serta pengalaman yang dilihat dan didengar oleh siswa tinggal.

Berdasarkan Tabel 4., untuk kategori sikap responden termasuk pada kategori positif dengan jumlah responden sebanyak 86 responden atau 72,26\%. Untuk kategori sikap ini dilihat dari cara siswa dalam menghadapi berbagai fenomena penggunaan Styrofoam sebagai wadah makanan dalam kehidupan sehari-hari, cara penanganan sampah Styrofoam dan cara siswa menemukan alternative solusi untuk mengganti wadah Styrofoam sebagai tempat makanan.

\section{KESIMPULAN}

Dari hasil penelitian dapat ditarik beberapa kesimpulan yaitu : Gambaran pengetahuan siswa SMAN Balung kelas XII MIPA tahun ajaran 2020/2021 akan bahaya penggunaan Styrofoam sebagai wadah makanan adalah termasuk dalam kategori sedang sebanyak 64 orang $(53,78 \%)$, kategori baik sebanyak 40 orang $(33,61 \%)$ dan kategori kurang sebanyak 15 orang $(12,6 \%)$. Sedangkan untuk gambaran sikap siswa SMAN Balung kelas XII MIPA tahun ajaran 2020/2021 tentang bahaya penggunaan Styrofoam sebagai wadah makanan dalam kategori positif sebanyak 86 orang $(72,26 \%)$ dan dalam kategori negatif sekitar 33 orang $(27,73 \%)$.

\section{SARAN}

1. Bagi siswa:

Disarankan bagi siswa siswa SMAN Balung kelas XII MIPA tahun ajaran 2020/2021 untuk terus meningkatkan pengetahuan mereka seputar bahaya penggunaan Styrofoam sebagai wadah 
Online: http://e-journal.sari-mutiara.ac.id/index.php/KesehatanMasyarakat

DOI: https://doi.org/10.51544/jkmlh.v6i1.1675

makanan sehingga diperoleh data yang lebih akurat yang dapat dijasikan dasar dalam mengambil langkah preventif untuk menghindari berbagai maslah yang ditimbulkan karena masalah ini. Sikap yang positif dalam menghindari penggunaan Styrofoam sebagai wadah makanan dan mencari alternative lain yang lebih aman bagi kesehatan juga harus terus ditingkatkan untuk menghindari bahaya penggunaan Styrofoam sebagai wadah makanan.

2. Bagi Peneliti Selanjutnya

Perlu dilakukan penelitian terkait kandungan yang terdapat dalam Styrofoam dan mensosialisasikan kepada masyarakat awam juga sangat membantu pengurangan dampak penggunaan Styrofoam sebagai wadah makanan.

\section{DAFTAR PUSTAKA}

Ilmiawati, C. (2017). Edukasi Pemakaian Plastik Sebagai Kemasan Makanan Dan Minuman Serta Resikonya Terhadap Kesehatan Pada Komunitas Di Kecamatan Bungus Teluk Kabung, Padang. Kecamatan Bungus Teluk Kabung, Padang:
Jurnal ilmiah pengabdian kepada masyarakat.

Notoatmodjo, S. (2011). Ilmu Kesehatan Masyarakat. Jakarta: Rineka Cipta.

Ryady, A. (2016). Ilmu Kesehatan Masyarakat. Yogyakarta: Penerbit Andi Offset.

Saputra, Y. (2016). Bahaya Styrofoam bagi Kesehatan dan Lingkungan.

Setyowati. (2017). Studi Sifat Fisis, Kimia, Morfologi Pada Kemasan Makanan Berbahan Styrofoam Dan LDPE (Low Density Polyethylene). http://journal.eng.unila.ac.id/index.p $\mathrm{hp} / \mathrm{mech} /$ article/viewFile/6/pdf.

Sumbung. (2012). Hubungan Antara Pengetaahuan Dan Sikap Dengan Tindakan Penjual Gorengan Di Kota Manado Dalam Mengurangi Penggunaan Kantong Plastik. Fakultas kesehatan masyarakat universitas sam ratulangi.

Widyaningsih, F. (2010). Pengetahuan, sikap dan tindakan pemilik tempat makanan jajanan tentang penggunaan Styrofoam sebagai kemasan makanan di kelurahan padang bulanselayang 1 kecamatan medan selayang tahun 2010. Medan: FKM USU. 